\title{
Loft Living and Gentrification: A Case for Istanbul Galata District Reading Change through Loft Designs
}

\author{
Umut TUĞLU KARSLI ${ }^{1^{\star}}$, Serpil ÖZKER ${ }^{2}$
}

\begin{abstract}
Following economic restructuring movements in 1950s, loft living first emerged as a result of gentrification process in New York City. In Istanbul, loft living became available recently and loft designs have represented in limited cases. This paper aims to examine loft living and loft designs in Galata, emerged as a result of micro-scale gentrification process in Istanbul. The research defines lofts in terms of spatial criteria; examines loft designs as an architectural result of gentrification process in Galata and aims to read the socio-cultural change through these designs. Selected lofts were examined through observations, interviews and photographs. The analysis table specifies names, construction dates, conversion dates, user profiles and according to criteria predetermined as part of the research, investigates what type these lofts correspond in structural and functional terms. Consequently, lofts emerged following the initial gentrification movements in Galata (original lofts converted for mixed-use) still exist in district; the number of 'lofts converted for commercial use' has increased due to the recent popularization of the area. Besides, 'semi-lofts converted for residential use' and 'imitation lofts built for residential use' reflecting just the commercial image of loft living and realized by large-scale construction firms, have emerged.
\end{abstract}

Keywords: loft interior design, loft living, loft conversion, socio-spatial change, gentrification

\section{Loft Yaşam ve Soylulaştırma: İstanbul Galata Bölgesi Örneği Değişimin Loft Tasarımlar Üzerinden Okunması}

Öz

1950'li yıllarda New York kentindeki soylulaştırma süreci, ekonomik yeniden yapılanma hareketleri sonucunda loft yaşamı üretmiştir. Loft yaşam, İstanbul'da yakın geçmişte ortaya çıkmış ve loft tasarımlar tekil örnekler ile görülmektedir. Bu çalışmanın amacı İstanbul'da mikro ölçekte meydana gelen soylulaştırma süreci sonucunda Galata'da ortaya çıkan loft yaşam ve loft tasarımları incelemektir. Çalışmada loftlar, mekansal ölçüt ve tipleri ile tanımlanmış; Galata'da soylulaştırma sürecinin mimari bir sonucu olarak loft tasarımlar incelenmiş ve bu süreçteki sosyo-kültürel değişimin bu tasarımlar üzerinden okuması gerçekleştirilmiştir. Seçilen örnekler, gözlem, röportaj ve fotoğraflar aracılığı ile incelenmiştir. Analiz tablosunda loftlar, isimleri, yapım tarihleri, dönüştürme tarihleri, kullanıcı profilleri ile incelenmiş ve belirlenen kriterlere göre bu loftların yapısal ve işlevsel açıdan hangi loft tipine karşılık geldiği analiz edilmiştir. Sonuçta, Galata'daki ilk soylulaştırma hareketleri ile ortaya çıkan ve 'karma kullanımlı orijinal loft' özelliği gösteren loftların, tekil örnekler ile halen varlığını sürdürdüğü; bölgeye artan ilgi nedeniyle özellikle 'ticari kullanımlı loft' özelliği gösteren loftların sayısının arttığı ve son

\footnotetext{
${ }^{1}$ Istanbul University, Faculty of Architecture, Department of Interior Architecture

2 Isik University, Faculty of Fine Arts, Department of Interior Architecture and Environmental Design

*Ilgili yazar/Corresponding author: umutt@istanbul.edu.tr

Gönderim Tarihi / Received Date: 01.05.2021

Kabul Tarihi / Accepted Date: 04.08.2021
} 
olarak büyük inşaat firmalarının tüm binayı satın alarak dönüştürdükleri 'konut kullanımlı ara loft' veya loft yaşamı bir ticari imaj olarak kullanarak inşa ettikleri 'konut kullanımlı sahte loft' özelliği gösteren yeni loftların ortaya çıktığı gözlemlenmiştir.

Anahtar Kelimeler: loft iç mekan tasarımı, loft yaşam, loft dönüşümü, sosyo-mekansal değişim, soylulaştırma

\section{Loft Design, Loft Conversions}

Dictionary of Architecture \& Construction defines loft as 'unceiled space beneath a roof, often used for storage', and loft building as 'a building containing open, unpartitioned floor space, used for commercial or industrial purposes' (Harris, 1993:499). After the end of the $20^{\text {th }}$ century, the word loft came to be defined as 'any large rehabilitated space whose original structure has been converted for domestic use' (Gomez, 2003:13). However, loft conversions may aim for uses alternative to residential use today. The concept of loft stands for not only residential use but also diverse uses within the scope of this research.

Loft living emerged in late 1950 s as a result of commercial and industrial translocation by artists, who looked for cheap spaces appropriate for multifunctional (live/work) use (Pamukçu, 2009:10). Economically depreciated areas in SoHo-New York, attracted artists with low incomes that needed places to live and work. The artists replaced the small businesses that failed to profit from manufacturing left the area. Former storages and factory areas gained residential identity with the new settlers. After the end of the 1960s, ascending status of arts and artists led to an increasing demand on converted loft spaces (Karagöz, 2007:137).

Architecturally characteristic buildings of the era consisted of carcass buildings with cast iron construction. They comprise of large glass facades and skylights and openplanned, high-ceiled, wide floors left from industrial buildings. These buildings have 5 to 10 floors and 180 to 900 square meters on each floor (Zukin, 1989:2). Artists like painters, sculptors, dancers and writers, who needed large areas to work, started to use these buildings as working and living places. The buildings, were transformed with low rental prices into mixed-use spaces where artists create and exhibit their works and live at the same time thanks to open-planned, high-ceiled spaces illuminated by large windows and suitable for flexible use. Artists created the identity and media created the image of the lifestyle of loft living. Like the settlers before them, the first generation of artists, artisans and actors, that moved into the loft here prior to 1970's had to leave the area due to the gentrification process; it is proposed that the most important reason for this is heavy demand on the area placed by the middle-upper class and real estate market (Taner, 2011:29). 'Loft living' transformed into a real estate term in America and Western Europe in 1960's (Pamukçu, 2009:6).

\subsection{Loft interior design and spatial criteria}

Conversion of industrial buildings in SoHo into living environments created a new interior design approach. The majority of these lofts have areas similar in size to other American houses; there are generally no inner walls and routine functions like eating, sleeping, entertainment, etc. are spread across the open space. Today, the identity change SoHo experienced also guides a change in loft architecture and user identity. Architectural characteristics show that these new buildings, albeit smaller than early lofts, are still spacious. They resemble early lofts with ceiling heights of 3,5-4,5 meters and facades with classic architectural details and become a type of estate that addresses upper- and middle-classes due to the aforesaid social and physical factors, 
gentrification and media influence (Taner, 2001:35). As lofts are converted from industrial buildings to serve uses like residence, home-office, art gallery, shop, workshop, etc. there are certain design criteria to defining lofts. The criteria can be subcategories into four categories: unpartitioned open plan, large glass facade, high ceiling and exposed structure:

\section{- Unpartitioned open plan}

Loft spaces are designed with an open plan to serve industrial purposes. All units in a loft converted to adopt new functions are positioned in an open system, except for certain functional and decorative preferences (Karagöz, 2007:7). Functions in a loft are generally divided by mobile elements, such as curtains, cabinets and furniture, instead of walls.

\section{- Large glass facades}

Lofts are illuminated through large windows, which are characteristic of industrial buildings and are 2-2,5-meter-high in average. Some lofts feature skylights or sunroofs in order to increase the amount of light in the space (Karagöz, 2007:6).

\section{- High ceiling}

Although lofts do not serve industrial functions, they appear in industrial scales in terms of dimensions. Ceilings are much higher than prescribed by the present residential architecture (about 3,5-4,5 meters) (Taner, 2011:36).

\section{- Exposed structure}

Fixed constructional components of lofts are not concealed. Timber or steel joists of the structure, naked walls, columns, posts, conditioning channels, plumbing elements and electric cables are generally exposed. It is proposed that exposed structure is the characteristic appearance of lofts, which are initially designed as storages, factories or workshops (Karagöz, 2007:5). Especially in new lofts, this characteristic is interpreted as exposed constructional components (Taner, 2011:41).

\subsection{Loft types}

This study deals with lofts to be analyzed in the last section of loft types under two headings, structural and functional, in order to provide a conceptual framework. Lofts are studied depending on whether they are conversions or new constructions in structural terms, and according to their new uses in functional terms.

\subsubsection{Loft types in structural terms}

The criteria stipulated in the study are mostly observed in newly built lofts; however, they do not constitute as critical design criteria as early lofts. It is observed that new buildings are defined as lofts especially in US where industrial building stock runs out. These are either conversions of old buildings or new buildings where the concept of loft is implemented in the design (Taner, 2011:41). In this context, loft types are examined in structural terms under three headings proposed by Özker (2014):

- Original loft: Original lofts are structures converted from factories, workshops or storages which lost their significance in $20^{\text {th }}$ century and they incorporate fixed architectural elements, exposed construction materials and natural lighting. They meet all the design criteria for lofts, such as unpartitioned open plan, large glass facade, high ceiling and exposed structure and are created by adaptive reuse of industrial buildings.

- Semi loft: Semi lofts are structures without historical value or lost their historical value and original identity and converted to serve alternative uses. They do not meet all the 
design criteria of lofts, however make references to industrial structures. A part of their construction material is exposed and their real identity is transformed by the use of artificial materials.

- Imitation loft: The most important characteristic of imitation lofts is that they are new constructions and not conversions of industrial structures. They are new residences built around the commercial image of lofts. Contrary to architectural criteria of lofts, they stand out with high-quality craftsmanship and expensive materials and bear similarities to luxury residential projects designed according to commercial concerns of the present time.

\subsubsection{Loft types in functional terms}

Loft conversions were initially performed in SoHo-New York, in the 1950's into the 'livework' use. However, functional purposes of the conversion of the lofts as industrial structures vary. Loft types can be examined in functional terms under four headings, residential, commercial, public/cultural and mixed-use:

\section{-Loft converted for residential use}

This subcategory is divided to loft-apartments and loft houses. Demi-lofts, or loftapartments, are the divided conversion of the original spacious loft into a smaller residence. Size of the original loft affords more than one residence. Loft houses are detached houses designed in loft criteria as home style lofts or townhouse lofts (Karagöz, 2007:65). They contain living functions unpartitionally or in a partly divided space.

\section{- Loft converted for commercial use}

Commercial lofts are converted for commercial purposes and they do not contain residential use. They are also used as restaurants, hotels or even retail shops according to environmental conditions. Today, they are generally popular as commercial offices.

\section{- Loft converted for cultural/public use}

They are frequently used for cultural/public purposes after conversion of large-scale industrial structures into schools, museums, art galleries, libraries, etc. Their high ceilings and broad spaces in open plans offer uses such as exhibition galleries and museums, which are the most prevalent types of loft converted for cultural/public use.

\section{- Loft converted for mixed-use}

They can serve several functions simultaneously as large industrial structures in unpartitioned open plans with high ceilings. Lofts with residential-commercial, residential-cultural/public, and commercial-cultural/public uses are categorized as mixed-use lofts. The most frequently seen type is live-work loft, which incorporates residential-commercial use. This type of lofts are horizontally divided with mezzanines and vertically divided with light separators. Live-work lofts of the artists in SoHo belong to this type.

\section{Loft Living And Gentrification}

The process of gentrification generally involves middle and upper class settling in and renovating obsolete urban historic areas with low incomer and poor residents to accommodate their own lifestyle (Islam \& Ciravoğlu 2006). Sociologist Ruth Glass coined the term in 1964 to mean the influx of wealthier individuals into cities or neighborhoods who replace working or lower-classes already living there (Glass, 
1964:18). Hamnett (1984) defines gentrification as 'a physical, economic, social and cultural phenomenon, commonly involves the invasion by middle-class or higher income groups of previously working-class neighborhoods or multi-occupied 'twilight areas' and the replacement or displacement of many of the original occupants'. Theorists identified phases of gentrification with waves. Artists, designers and academicians took interest in urban residences vacated during suburbanization process, which is defined as the first wave of the gentrification process and is called 'marginal gentrification'. Van Criekingen and Decroly (2003) define marginal gentrification as neighborhood revitalization associated with an incoming middle-class that is 'richer in cultural capital than in economic capital' and 'gentrification' with an influx of affluent classes that transforms the former low income neighborhood into a wealthy area. During this initial wave of gentrification, marginal gentrifiers, who are called pioneers, initiate the process by consciously or unconsciously pointing out to an urban area with cultural potential. During the second and third waves of gentrification, identity of the gentrifiers changes. Ergun (2004:392) suggests "the appearance of artists in these areas has led to the introduction of galleries, coffee houses, rock clubs, and this night life has attracted gentrifiers to the area as well". Second-wave gentrifiers, who are defined as cultural intermediaries, consciously use art as a cultural policy during the process. During the third wave, gentrifiers are business owners, trend followers, wannabes, people of means and profiteers. The fourth wave mostly consists of macro-size state-sanctioned large-scale investment projects (Dalgıçer, 2011:16).

\subsection{Gentrification process in Istanbul}

The concept of gentrification did not have significance in urban research agenda in Turkey until the 1990s. In the 1960s, central areas of Turkish cities staged a rapid construction process of apartment buildings in a demolish-built-sell method, supported by unanimous approval of almost all classes and spheres and state incentives. Lack of conservation awareness accelerated the process of the destruction and conversion of building stock into apartment buildings. This process came to halt in the 1990s. Because gentrifiable housing stock was scarce, low quality and not very accessible and due to legal framework of conservation, fragmentation of ownership, the earthquake risk, etc., gentrification in Turkey was not as prevalent as in London, New York, Boston, etc. (Güvenç, 2006). Historic districts that used to house minorities, are the most frequent stages of gentrification in Istanbul. Minorities left or had to leave their districts due to a series of incidents after the 1950s. These urban residences served as alternative residences for immigrants and became physical, economic and sociocultural 'areas of depression'. The transformation process in historic urban residential areas in Istanbul took a new shape within the context of new social and spatial dynamics brought on by economic restructuring, especially after the year of 1980, and the first steps of gentrification were taken by individual movements. Şişmanyazıcı \& Turgut Yıldız examine the gentrification process in Istanbul into four phases:

- The first wave (1980): The process was shaped by individual interventions (Arnavutköy, Ortaköy, Kuzguncuk).

- The second wave (1980-1990): The process was shaped mostly by individual interventions according to cultural and entertainment events (Galata, Cihangir, Asmalımescit).

- The third wave (1996): The process was shaped by organized public investment projects (Fener, Balat).

- The fourth wave (2000-...): Farther-reaching but socially weaker projects were prepared as part of expropriation studies (Sulukule, Tarlabaşı, Fener-Balat, Ayvansaray, Süleymaniye). Sulukule Project initiated renovation projects of the fourth wave, which adopt economic development and profit as the most 
important dynamics; investors play the leading role in the process (Şişmanyazıcı \& Turgut Yıldız, 2010).

The first and second waves of the gentrification of Istanbul continue in the micro-scale; the biggest reason for this is that the interventions of gentrifiers with medium incomes, who are called 'academic, bohemian class' by sociologist Çağlar Keyder, are in the individual scale. According to Keyder, the most important reason they strive for gentrification is that 'they prefer buying and restoring a high-ceiled building from the 1920s in Arnavutköy, Galata, or Cihangir to buying an apartment from a residence project in Fulya' (Ciravoğlu and Islam, 2006). Kuban (2006) makes a similar statement. Kuban suggests there are two important qualities that gentrification disticts in Europe have but Turkey and Istanbul do not: '1. Historic buildings were preserved. In other words, what is gentrified is history and not the building. 2. People that undertake maintenance of these old buildings are the gentrified people of the society in terms of intellectuality and not money.' In this sense, he suggests 'only Galata and Beyoğlu stage a real 'gentrification' phenomenon in Istanbul' and however, 'another reason real gentrification takes place in Galata is the European characteristics of the area originating from its history' (Kuban, 2006).

\subsection{Gentrification and loft living in Galata}

As global economy perception changed in the 1950s, the process of industrialization started in Istanbul. Throughout the process, working class replaced the social class and commercial functions were replaced by workshops. When the minorities residing in Galata and Pera left the district, commercial units, light industry workshops and storages replaced a part of the residences in the area. Galata was gradually impoverished during functional and social transformations (Karagöz, 2007:149). In the 1980s, a new middle-class emerged with economic restructuring and new investment opportunities produced by private capital. Social and spatial transformations of the 1980s, primarily in villages along the Bosphorus, were observed in Galata and Pera in early 1990s. The first phase of the transformation of Galata started when architects and artists bought or rented neglect high-ceiled buildings, appropriate for studio use (Islam, 2005:130). During this process, old and small-scale workshops were converted mostly for mixed-use (live-work loft) by marginal gentrifiers in a similar manner to SoHo. Loft living that emerged in Galata continued with media workers, academicians and gentrifiers from the new middle-class. In the 2000s, loft living in Galata regenerated the district altogether. Commercial units like cafés, fashion houses, etc. defined as 'cultural intermediaries,' were observed in the Galata district after the early 2000s (Dalgıçer, 2011:46). According to Islam's research (2002), the professionals, academicians, architects, journalists, caricaturists, film directors bought 40 historical buildings and restored them between 1999 and 2001 in Galata. There are still light industry workshops operating in Galata. The region is in the initial phases of gentrification and new gentrification actors come to the district.

\subsection{Reading transformation in Galata through loft designs}

The ongoing gentrification process in Galata, which started between 1980 and 1990, constitutes the basis of loft living in Istanbul. Accordingly, lofts in Galata were researched in terms of structural and functional criteria and 13 lofts were selected to show loft design examples in Galata. Loft conversions selected in the area were examined and data regarding location, construction and conversion date, user profile, interior characteristics (floor plans, sections, materials), original and new use of these loft designs were obtained through field observations, interviews with users and photo shoots of lofts. 
The analysis table specifies names, construction dates, conversion dates, user profiles of the lofts and according to criteria predetermined as part of the research, investigates what loft type these lofts correspond in structural and functional terms (Table 1).

Table 1. Analysis of Loft Design Examples in Galata

\begin{tabular}{|c|c|c|c|c|c|c|c|c|c|c|c|c|}
\hline \multicolumn{5}{|c|}{ Information about Loft } & \multicolumn{5}{|c|}{$\begin{array}{l}\text { Loft Type } \\
\text { in Structural Terms }\end{array}$} & \multicolumn{3}{|c|}{$\begin{array}{l}\text { Loft Type } \\
\text { in Functional Terms }\end{array}$} \\
\hline 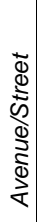 & 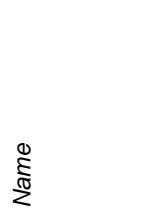 & 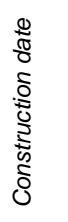 & $\begin{array}{l}0 \\
\frac{0}{0} \\
0 \\
\frac{0}{5} \\
0 \\
0 \\
0 \\
0 \\
0\end{array}$ & 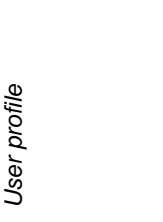 & 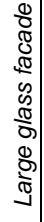 & 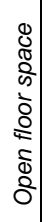 & 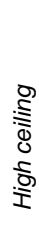 & 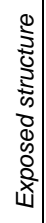 & 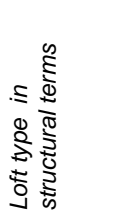 & 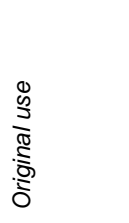 & 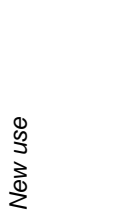 & 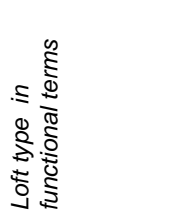 \\
\hline \multirow{6}{*}{$\begin{array}{l}\frac{x}{0} \\
\frac{0}{0} \\
\frac{0}{1} \\
\overline{0} \\
\frac{0}{3}\end{array}$} & $\begin{array}{l}\text { Lüleci } \\
\text { Hendek } 54\end{array}$ & 1920 & 2006 & $\begin{array}{l}\text { high-income } \\
\text { group } \\
\text { professionals }\end{array}$ & + & - & + & - & semi loft & $\begin{array}{c}\text { residence } \\
+ \\
\text { workshop }\end{array}$ & residence & $\begin{array}{c}\text { loft converted } \\
\text { for residential } \\
\text { use }\end{array}$ \\
\hline & Ipera 25 & 2011 & new & $\begin{array}{l}\text { high-income } \\
\text { group } \\
\text { professionals }\end{array}$ & + & + & + & - & $\begin{array}{l}\text { imitation } \\
\text { loft }\end{array}$ & - & residence & $\begin{array}{l}\text { loft built for } \\
\text { residential use }\end{array}$ \\
\hline & $\begin{array}{l}\text { Hacı Mimi 1- } \\
2\end{array}$ & 2010 & new & $\begin{array}{l}\text { high-income } \\
\text { group } \\
\text { professionals }\end{array}$ & + & - & + & - & $\begin{array}{l}\text { imitation } \\
\text { loft }\end{array}$ & - & residence & $\begin{array}{l}\text { loft built for } \\
\text { residential use }\end{array}$ \\
\hline & Ali Hoca 6 & 1970 & 2006 & $\begin{array}{l}\text { high-income } \\
\text { group } \\
\text { professionals }\end{array}$ & + & + & + & - & semi loft & office & residence & $\begin{array}{c}\text { loft converted } \\
\text { for residential } \\
\text { use }\end{array}$ \\
\hline & $\begin{array}{l}\text { Tatar Beyi } \\
18\end{array}$ & 1880 & 2006 & $\begin{array}{l}\text { high-income } \\
\text { group } \\
\text { professionals }\end{array}$ & + & + & + & - & semi loft & $\begin{array}{c}\text { residence } \\
+ \\
\text { workshop }\end{array}$ & residence & $\begin{array}{c}\text { loft converted } \\
\text { for residential } \\
\text { use }\end{array}$ \\
\hline & $\begin{array}{l}\text { Kota Food } \\
\text { for Friends }\end{array}$ & $\begin{array}{l}20^{\text {th }} \\
\text { cent. }\end{array}$ & 2009 & $\begin{array}{l}\text { high-income } \\
\text { group } \\
\text { professionals }\end{array}$ & + & + & + & + & $\begin{array}{l}\text { original } \\
\text { loft }\end{array}$ & workshop & restaurant & $\begin{array}{c}\text { loft converted } \\
\text { for commercial } \\
\text { use }\end{array}$ \\
\hline $\begin{array}{l}\frac{\pi}{\pi} \\
\frac{\pi}{\pi} \\
0\end{array}$ & $\begin{array}{l}\text { Galata } \\
\text { House }\end{array}$ & 1904 & 1999 & $\begin{array}{l}\text { high-income } \\
\text { group } \\
\text { professionals }\end{array}$ & + & + & + & + & $\begin{array}{c}\text { original } \\
\text { loft }\end{array}$ & $\begin{array}{l}\text { jewelry } \\
\text { and metal } \\
\text { workshop }\end{array}$ & restaurant & $\begin{array}{c}\text { loft converted } \\
\text { for commercial } \\
\text { use }\end{array}$ \\
\hline \multirow{4}{*}{$\begin{array}{l}\frac{\varepsilon}{0} \\
\frac{0}{2} \\
\Psi \\
\frac{1}{\frac{1}{\pi}} \\
\frac{\pi}{2} \\
\omega\end{array}$} & $\begin{array}{l}\text { Building } \\
\text { Idea Eng. }\end{array}$ & 1950 & 2006 & designers & + & + & + & + & $\begin{array}{c}\text { original } \\
\text { loft }\end{array}$ & $\begin{array}{l}\text { electric- } \\
\text { chandelier } \\
\text { workshop }\end{array}$ & $\begin{array}{c}\text { design } \\
\text { workshop } \\
+ \\
\text { café } \\
\end{array}$ & $\begin{array}{c}\text { loft converted } \\
\text { for commercial } \\
\text { use }\end{array}$ \\
\hline & $\begin{array}{l}\text { Dance } \\
\text { Meeting } \\
\text { Studio }\end{array}$ & $\begin{array}{l}20^{\text {th }} \\
\text { cent. }\end{array}$ & 2002 & artists & + & + & + & + & $\begin{array}{c}\text { original } \\
\text { loft }\end{array}$ & $\begin{array}{l}\text { lighting } \\
\text { workshop }\end{array}$ & $\begin{array}{l}\text { dance } \\
\text { studio }\end{array}$ & $\begin{array}{c}\text { loft converted } \\
\text { for } \\
\text { cultural/public } \\
\text { use }\end{array}$ \\
\hline & Mimarhane & $\begin{array}{l}20^{\text {th }} \\
\text { cent. }\end{array}$ & 2005 & architects & + & + & + & - & semi loft & $\begin{array}{l}\text { lighting } \\
\text { workshop }\end{array}$ & $\begin{array}{l}\text { arch. } \\
\text { design } \\
\text { studio }\end{array}$ & $\begin{array}{l}\text { loft converted } \\
\text { for commercial } \\
\text { use }\end{array}$ \\
\hline & $\begin{array}{l}\text { Mavra } \\
\text { Design Cafe } \\
\text { Workshop }\end{array}$ & $\begin{array}{l}20^{\text {th }} \\
\text { cent. }\end{array}$ & 2005 & designers & + & + & + & - & semi loft & $\begin{array}{l}\text { electric- } \\
\text { chand. } \\
\text { workshop }\end{array}$ & $\begin{array}{c}\text { design } \\
\text { workshop } \\
+ \\
\text { café } \\
\end{array}$ & $\begin{array}{c}\text { loft converted } \\
\text { for commercial } \\
\text { use }\end{array}$ \\
\hline \multirow{2}{*}{$\begin{array}{l}0 \\
\frac{0}{0} \\
0 \\
0 \\
\frac{0}{\overline{7}} \\
0\end{array}$} & $\begin{array}{l}\text { Zuhal Music } \\
\text { Store }\end{array}$ & $\begin{array}{l}20^{\text {th }} \\
\text { cent. }\end{array}$ & 2007 & artists & + & + & + & + & $\begin{array}{c}\text { original } \\
\text { loft }\end{array}$ & $\begin{array}{c}\text { musical } \\
\text { instr. } \\
\text { workshop }\end{array}$ & $\begin{array}{l}\text { music } \\
\text { store }\end{array}$ & $\begin{array}{c}\text { loft converted } \\
\text { for commercial } \\
\text { use }\end{array}$ \\
\hline & $\begin{array}{l}\text { Muzaffer } \\
\text { Akyol's Loft }\end{array}$ & 1885 & 2010 & painter & + & + & + & + & $\begin{array}{l}\text { original } \\
\text { loft }\end{array}$ & workshop & $\begin{array}{c}\text { residence } \\
+ \\
\text { workshop }\end{array}$ & $\begin{array}{l}\text { loft converted } \\
\text { for mixed-use }\end{array}$ \\
\hline
\end{tabular}


As a result of the analysis, it is determined that there are 3 basic types of loft design demonstrating socio-cultural pattern existing in Galata. Lofts with 'original loft converted for mixed-use (live-work loft)' are one of these types. These lofts are similar to the lofts of SoHo-New York, converted after the initial gentrification movements in Galata by intellectually rich artist-designer users with cultural capital, are still in existence in the district through individual examples (Fig. 1).
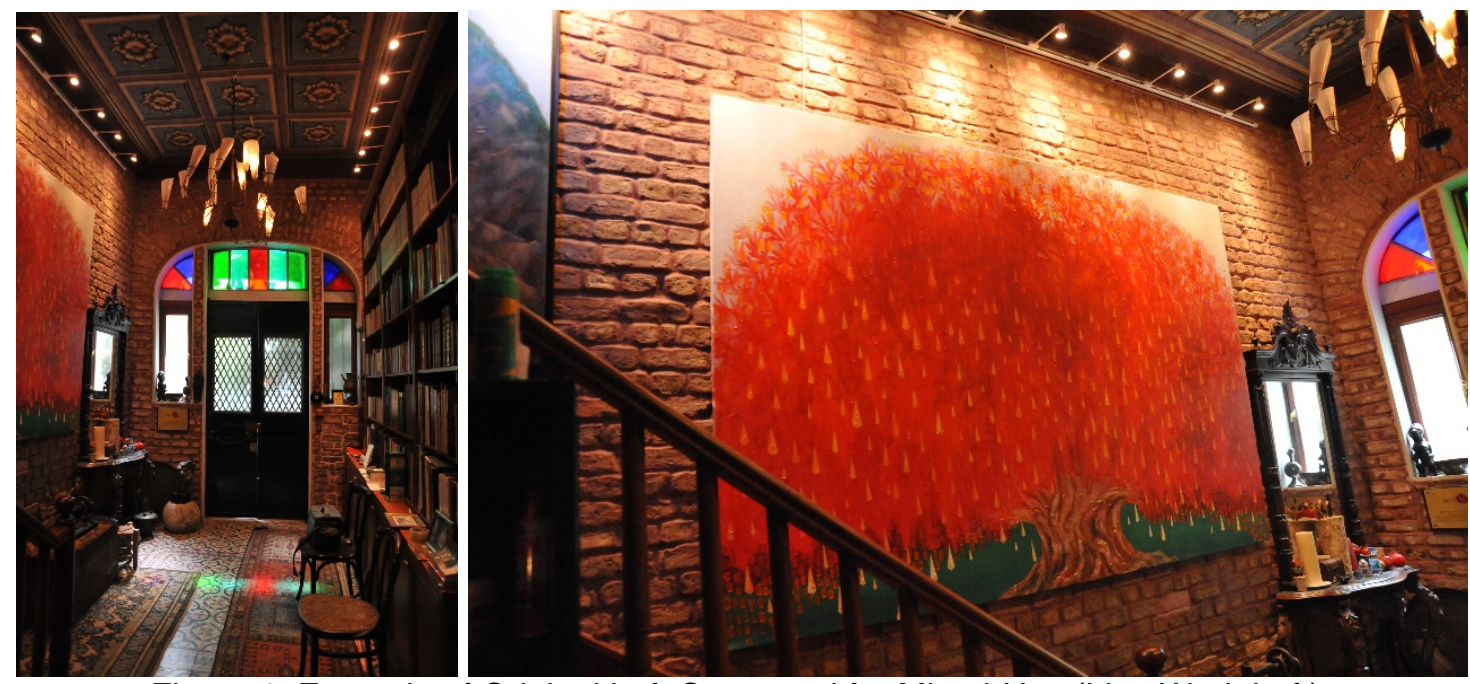

Figure 1. Example of Original Loft Converted for Mixed-Use (Live-Work Loft):

Painter Muzaffer Akyol's Loft (Photograph: Author)

Second type of lofts are 'Original or semi-lofts converted for cultural or commercial use' and are generally operated by the 'cultural intermediary' social class, have emerged due to the increasing demand on the district in recent years. These lofts are used as boutique, art gallery, café, music store, dance studio etc. (Fig. 2).

Last type of lofts analysed in the district are 'imitation lofts' and 'semi-lofts' converted for residential use. Imitation lofts (new construction) are not converted but built-in order to profit by large-scale investment firms for professionals with economic capital (Fig. 3). Similarly, 'semi-lofts converted for residential use' are converted by the investment firms through buying whole building to appeal high-income group.
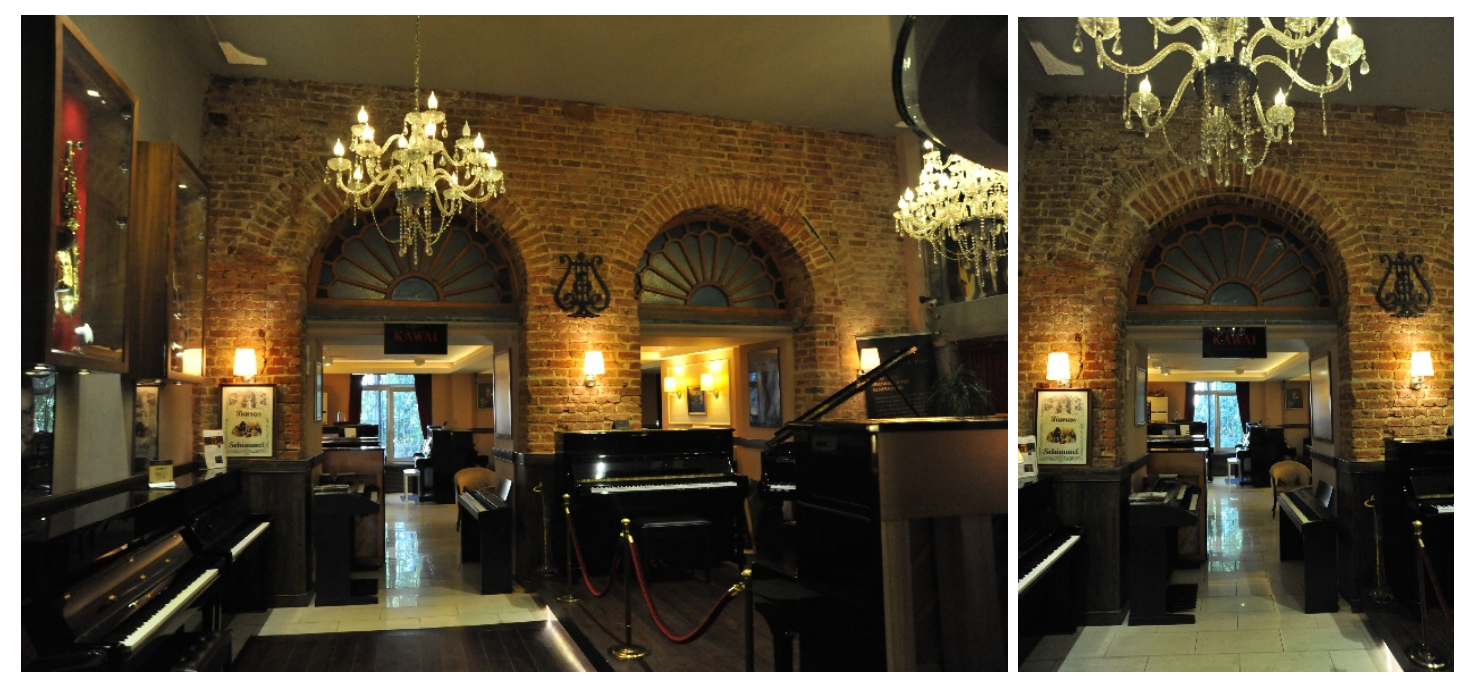

Figure 2. Example of Original Loft Converted for Commercial Use: Zuhal Music Store (Photograph: Author) 


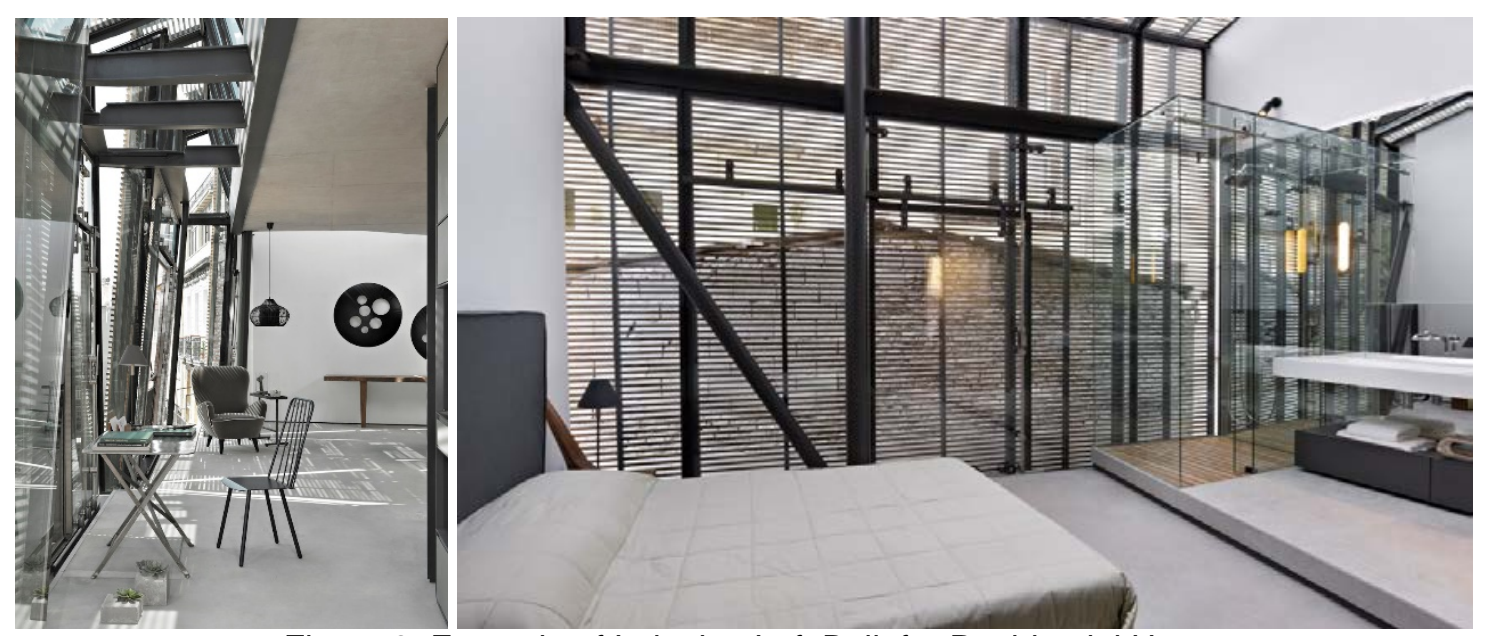

Figure 3. Example of Imitation Loft Built for Residential Use: Ipera 25 (Photograph: Ali Bekman, URL-1)

\section{Discussion and Conclusion}

As globalization rapidly takes effect in Istanbul, gentrification has become a process during which local governances have active roles as an economic strategy. Galata has been a potential district in gentrification process with buildings from the late $19^{\text {th }}$ century overlooking the Bosphorus, high-ceiled workshops and close location to Istiklal Avenue. In the initial process of gentrification, artists, architects and bohemian 'marginal gentrifiers' converted old workshops in Galata into mixed-use lofts (live-work lofts). Rehabilitating environment and the appeal of loft living attracted 'cultural intermediaries' first and large-scale investors later. The study primarily examines the literature on the concepts of loft and gentrification, and intends to read the sociocultural change Galata district has gone through during the gentrification process through loft designs. Lofts converted between 1990 and 2000 were mostly mixed-use original lofts converted by users like architects, designers and academicians. Although, it is analyzed that there are individual examples of the same type among the lofts converted since 2000. Secondly, it was observed that loft types have underwent a change towards two directions according to the altering socio-cultural attributes of the district. The first is the commercial use of lofts by cultural intermediaries (boutiques, cafés, recreation and entertainment venues). The most important reason for this is the emergence of spaces of 'design and fashion-oriented consumption' ascribed to the district according to contemporary tendencies and globalization. This approach transformed Galata into an attraction center and increased demand on the district. The second type of loft that emerged in Galata after 2000 is the semi or imitation loft converted for residential use. The most important reason for the emergence of imitation lofts is the fact that non-proprietary buildings in the area were bought and demolished by large-scale investors to build sheltered residential areas, which address the highincome group. These lofts were named imitation lofts because they are built and not converted and they are used as a commercial image without meeting loft design criteria. Most of these loft buildings are leased daily at costly rents.

The lives of lower-medium income class and high-income class in Galata are still integrated. Based on the analysis, the worst-case scenario is social segregation among residents, separation of the lower-middle class from the district and transformability of the district according to the needs of a certain class, including private security, luxurious cafés, restaurants and stores. There are possible precautions to prevent this scenario. First, lower-middle class may be kept in the area by providing legal and 
financial aid in order to help resident users renovate outdated residences. Also, public areas are required along with private and public areas, cafés-bars and business places available only to upper-middle and upper classes. This is possible through conversion of lofts converted for cultural/public use.

\section{References}

Ciravoğlu, A., Islam, T. (2006). Çağlar Keyder: soylulaştırma, kapitalizmin kentsel mekan düzeyinde yansımasıdır (Çağlar Keyder: gentrification is a reflection of capitalism on urban space). Mimar.ist, 21, 46-51.

Dalgiçer, M. (2011). Beyoğlu'nun Soylulaştırılmasında Münferit Hareketler: Galata Bölgesi. (Individual Movements in the Gentrification of Beyoğlu: Galata District) Master's thesis, Istanbul Technical University, Istanbul.

Ergun, N. (2004). Gentrification in Istanbul. Cities, 21(5), 391-405.

Glass, R. (1964). Aspects of Change, in Centre for Urban Studies London. London: Macgibbon and Kee.

Gomez, L. (2003). Lofts, living, working and trading in Loft. China: H.F. Ullmann.

Güvenç, M. (2006). Gentrification kavramı nasıl Türkçeleştirilmeli (How should we translate gentrification?). Mimar.ist, 21, 39-45.

Hamnett, C. (1984). Gentrification and Residential Location Theory: a Review and Assessment in D. Herbert, R.J. Johnston (Eds.). Geography and the Urban Environment: Progress in Research and Applications. 282-319. New York: Wiley and Sons.

Harris, C. M. (1993). Dictionary of Architecture \& Construction, 2nd edition. USA: Mc Graw-Hill Inc.

Islam, T. \& Ciravoğlu, A. (2006). Soylulaştırma ve Istanbul (Gentrification and Istanbul). Mimar.ist, 21, 37-38.

Islam, T. (2002). Gentrification in Istanbul: A Comparison of Different Cases, in Upward Neighborhood Trajectories: Gentrification in a New Century Conference, Glasgow, Scotland.

Islam, T. (2005). Outside the Core: Gentrification in Istanbul in R. Atkinson, G. Bridge (Eds.). Gentrification in a Global Context, the New Urban Colonialism. New York: Routledge.

Karagöz, Z. (2007). Tasarımda Loft Anlayışı (Loft Concept in design). Master's thesis, Istanbul Kultur University. Istanbul.

Kuban, D. (2006). Soylulaştırma (Gentrification). Mimar.ist, 21, 57-60.

Özker, S. (2014). A Review of Lofts as Housing in Istanbul. Open House International, 39(1), 56-68. 
Pamukçu, K. Ö. (2009). Ticari ve Endüstriyel Yer Değiştirmenin Sonucu Olarak; Loft Mekanlarının Değerlendirilmesi. (Evaluation of 'Lofts' as a Consequence of Commercial and Industrial Translocation) Master's thesis. Yildiz Technical University, Istanbul.

Şişmanyazici, B., Turgut, H. (2010). Tarihi kentsel alanlarda toplumsal ve mekansal yeniden yapılanma: Fener ve Balat örneği (Social and spatial restructuring in historic urban areas: example of Fener and Balat), Mimarlık, 352, 28-35.

Taner, S. (2011). Istanbul Endüstri Yapılarının Loft Kavramı Çerçevesinde Yeniden Işlevlendirilmesi. (Adaptive Reuse of Industrial Buildings in Istanbul in Context of Loft Concept) Master's thesis, Istanbul Technical University, Istanbul.

Van Criekingen, M. \& Decroly, J. M. (2003). Revisiting the diversity of gentrification: neighbourhood renewal processes in Brussels and Montreal. Urban Studies, 40(12), 2451-2468.

Zukin, S. (1989). Loft living, Culture and Capital in Urban Change. New Jersey: Rutgers University Press.

\section{Internet References}

URL-1. https://www.archdaily.com/291739/ipera-25-alatas-architecture consulting/ 509c4affb3fc4b2c5500004f-ipera-25-alatas-architecture-consultingphoto?next_project=no, last accessed on 03.02.2021 